\title{
FROM THE CHRONICLE OF THE
} CAPINOVO MONASTERY

\section{"ST. NICOLAI WONDERWORKER"}

\section{Pavlina Vladeva, pvladeva@gmail.com}

\author{
Community centre „Nadejda -1869", Veliko Tarnovo, Bulgaria
}

Abstract: The subject of this study is the chronicle of the Kapinovo monastery "St. Nicolai the Wonderworker". The royal monastery was founded in 1272 with the patronage of King Constantine Tych-Assen. It is one of the oldest and largest Bulgarian monasteries. During the Ottoman rule, it was pillaged, devastated and set ablaze by kardzhalii (turkish outlaws). It was rebuilt twice in 1835 and 1856. During the Revival it was a significant spiritual, enlightenment and revolutionary center. It is closely linked to the struggles for an independent church, nationwide education and political freedom. In 1830 a monastery school was founded there. Freedom fighters sougters refuge in the monastery: Velchova plot 1835, Captain Dyado Nikola's uprising 1856, Hadji Stavreva rebellion 1862. Under the Russo-Turkish wars (1877-1878) the monastery shelters refugees from the town of Elena, which was burned down by the Turks in November 1877. A Russian military infirmary for the wounded warriors was also organized. Lientenant Colonel Georgi Ulagai and 32 Russian soldiers are buried in the yard of the monastery. Four monks from the holy cloister have reached the pinnacles of hierarchical service by being elected bishops. The monastery is seen as a fortress of Bulgarian spirituality and guardian of our cultural and historical heritage.

Keywords: Kapinovo Monastery „St. Nicolai the Wondenworker”, Independent Church, Abbot, Revolutionary Center, Bishop,

Russo-Turkish Wars (1877-1878), Russian Military Infirmary, Refugees

\section{ИЗ АЕТОПИСА НА КЪПИНОВСКИЯ}

\section{МАНАСТИР „СВ. НИКОААЙ ЧУАОТВОРЕЦ”}

\section{Пав^ина В^алева, pvladeva@gmail.com}

\author{
Читалище „Належла 1869" Велико Тьрново, Бьлгария
}

Резюме: Обект на проучване е летописа на Кьпиновския манастир „Св. Николай Чудотворец”. Царският манастир е основан през 1272 г. с покровителството на цар Константин Асен -Тих Той е елин от най-старите и най-големи български манастири. По време на Османското влаличество е ограбван, опустошаван и опожаряван 
От кърАжалийски банди. Възстановяван е Ава пьти през 1835 и 1856 г. По време на Възраждането е значим Ауховен, просветен и революционен центьр. Той е тясно свьрзан с борбите за независима цьрква, национално образование и политическа свобола. През 1830 г. в него е открито килийно училище. Борците за свобода намират убежище в манастира: Велчова завера 1835, Въстанието на капитан Аяло Никола 1856 г., Халжи Ставрева буна 1862 г. По време на Рускотурската война (1877-1878) манастирьт приютява бежанците от граА Елена, опожарена от турците през ноември 1877 г. Руски военен ^азарет за ранените войни е организиран. Полполковник Георги Улагай и 32 руски войника са погребани в Авора на манастира. Четири монаха от светата обител са стигнали Ао върховете на иерархическото служене, като са избрани за епископи. Манастирьт е крепост на българската Ауховност и пазител на нашето културноисторическо наслеАство

КАючови Ауми: Къпиновски манастир „Св. Николай Чулотворец", независима цьрква, игумен, революционен центьр, епископ, Руско-турска война (1877-1878), Руски военен лазарет, бежанци

\section{1. КЪПИНОВСКИ МАНАСТИР „СВ. НИКОААЙ ЧУАОТВОРЕЦ"}

Къпиновският манастир „Св. Николай Чудотворец” е основан през 1272 г. спореА налпис върху източната фрасала с покровителството на цар Константин Тих-Асен (1257-1277). Царският манастир е еАин от най-

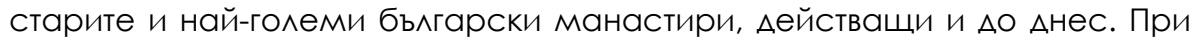
палането на Търновското царство пол османско влаАичество е опожарен и изоставен. През XVII в. манастирьт е възстановен благоларение на упоритостта на селяните от съседните села. Тъй като турските власти не давали офрициално разрешение за възстановяване Аейността на манастира, хората го изгражАали през нощта, а новите манастирски сгради опушвали С огън, за да изглежАат стари. САеА това Кьпиновският манастир е опожаряван още няколко пьти, но не е престава^ да фоннционира. Най-ранният ценен паметник, произхожлащ от Къпиновския манастир, е т. нар. „Къпиновски триптих-поменик“ е от 1700 г. Той е с размери 31/63 см. Пьрвите сведения за историята на манастира са от края на XVII век и началото на XVIII век. Той разкрива важни моменти от историята на светата обител. ", Поменикът-триптих има селем разпределения, по две колони в страни и три в средата: 1. - за православните християни ктитори и приложници; 2. - за усопшите слуги и старци монастирски; 3. - за архиереите; 4. - за иеромонасите и 
монасите; 5. - за игумените; 6. - за монахините; 7. - за благочестивите християни." (Tsonev, 1937, р. 18). През 1934 г. профо. Крьстю Миятев пише студия за триптиха-поменик. Анес той се съхранява в Националния археологически музей в София. В манастира се пазят ценни богослужебни книги. Красиви са запазените резбован фрриз, олтарни царски Авери с резбовани елементи, и резбован влалишки трон от XVIII век, характерни за Тревненската резбарска школа. Манастирската цьрква е богата и с икони от XVIII и XIX в. В началото на XIX век започва обновяването на манастира по времето на Архим х.Неdрталим. През 1835 г. възстановяването на манастирския храм, жилищните и сервизните помещения, магерницата, мазите, килиите и други е дело на уста Коста Арнаут и Авама майстори от Аряново - Пенчо и Рачо. Те построяват нова съборна цьрква „Св. Николай”. Тя е продьлговата, еАнокорабна базилика без купол, изгралена изцяло от камък. На запаА се Аопьлва от открита нарктика с Аьрвени парапети и колони. В предлверието на външната

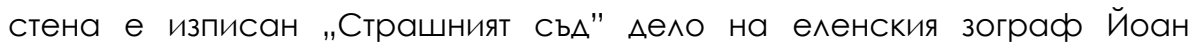
Попович. Със средства на братя Хорозови от Елена през 1856 г. започва най-амбициозното строителство в манастира. Тогава са изгралени Анешните Авуетажни жилищни постройки, като външната им стена е

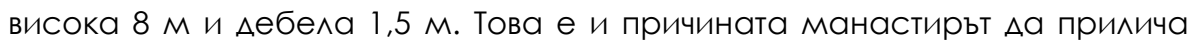
отвън на крепост. През 1864 г. е построен параклисьт „Въвеление Богородично" - монументален и красиво зографоисан храм. На запалната стена на вхола е разположен портрет на Авамата ктитори С модела на построените от тях сгради. В Авора има мальк открит параклис със стенописи „Благовещение“. ПреА параклиса са гробовете на Архим. х.Теолосий Хорозов и на Архим. Стедран х. Ралков.

\section{2. БЕАЕЖИТИ МИТРОПОАИТИ}

Чест е за Кьпиновската света обител като Ауховно-просветно огнище, че четирима бележити Ауховника служили в нея като архимандрити са Аостигнали върха на иерархическото служене в Българската църква като митрополити: Св. Софроний митрополит Врачански, И^арион митрополит Аовчански, Неофоит митрополит Преславски, И^арион митрополит Неврокопски. 
Св. Софрроний митрополит Врачански (поп Стойко В^аАиславов) (1739-1813) е ролен в граА Котел. През 1794 г. за игумен на манастира "Св. Николай Чудотворец" е избран Софрроний йеромонах Котленски. През сьщата голина е избран за митрополит на Врачанска епархия като Софрроний Врачански. През 1803 г. заминава за Букурещ и служи като Ауховно мице. Епископ Софроний Врачански е приеман от управляващите в Букурещ и от преАставителите на руското военно командване там за основен представител на българската общност. Среща се и с генерал Кутузов. Освещава знамето на Българската Земска войска. Соорроний Врачански е прьв последовател на Аелото на Св. Паисий ХиленАарски. Направил е Ава преписа на „История славянобългарска" през 1765 г. и 1781 г. През 1806 г. в (Рьмник) Анес граА Римник Въ^ча Софрроний Врачански издава пьрвата печатна книга на новобългарски език „Кириакодромион” („Неделник”). През 1861 г. пише автобиографричната си повест „Житие и страдание грешного Софррония". На 31 Аекември 1964 г. Софрроний Врачански е канонизиран от Българската православна цьрква.

И^арион митрополит Аовчански (Иван Иванов) (1800-1884) е ролен в махала Горни Чукани - граА Елена. През 1816 г. приема монашество като втори Ауховен син на игумена архимандрит х.Неорталим. В монашески постриг "Йоан Четец" получил името Иларион. Служи при търновските митрополити на Грьцката патриаршия като Аякон, иеродякон, архимандрит. От 1846 г. е протосингел на Търновската митрополия. През юни 1850 г. е въвелен в епископски сан в храма "Св. Аимитрий” в село Арбанаси като Аксополски епископ. Аве гоАини по-късно той е избран за Аовчански митрополит, КъАето светителствува 20 години (1852-1872). Той скъсва с Цариградската патриаршия и се присъединява към народните архиереи. През 1871 г. е председател на Българския Народен Събор в Цариграл, който изработва основния закон на българската църква - Екзархийския устав. На 12.ІІ.1872 г. е избран за пьрви бьлгарски Екзарх.

Поради напредналата си възраст слеА 4 Ани той си подава оставката. Избран е за КюстенАилски митрополит. Там работи 12 голини Ао блажената си кончина в КюстенАи^ на 2.ІІ.1884 г. Би^ е най-възрастният 
депутат в Учредителното събрание 1879 г. Неофоит митрополит Преславски е ролен в село Церова кория. Замонашва се в Къпиновския манастир. Бил е протосингеА на И^арион митрополит Аовчански. На 8 ноември 1865 г. избран за игумен на Етрополския манастир „Света Троица". На 24 юли 1871 г. е избран за къпиновски игумен. Като мъдьр кАирик и цьрковник през 1871 г. е хиротонисан за епископ Преславски.

И^арион митрополит Неврокопски (Иван Пенчев) (1850-1925) е ролен в село Церова кория. Приема монашеството в Кьпиновския манастир на 6 декември 1871 г. Учи в Петропавловската Ауховна семинария в Аясковец (1873-1878) и в ОАеската Ауховна семинария (1878-1884). Бил е учител в Солунската мъжка гимназия и в ОАринското Ауховно училище. На 18 август 1891 г. е рькоположен в иеромонашески сан в Цариграл и е изпратен за предселател на Серската цьрковна община. На 13 лекември 1892 г. е възведен в архимандритско Аостойнство. На 24 април 1894 г. е ръкоположен за митрополит Неврокопски.

\section{3. ЗАБЕАЕЖИТЕАНИ АРХИМАНАРИТИ}

Архим х. Неоталим е ролен в село Церова кория. Бил е еАин от най-забележителните игумени на манастира. Служил е найпродьлжително време 52 години (1794-1846). През 1795 г. манастира е опожарен, опустошен и разграбен от кърАжалийските разбойници начело с търновския войвола Кара Хисикирата. Иконите и старите ръкописни книги са изгорени. Игуменьт х. Неоталим взема само манастирския поменик-триптих и се спасява с монасите в близката гора. Х. Недрталим открива през 1830 г. килийно училище за полготовка на свещенослужители и учители (граматици). "Училищната Аейност и оставените хроники определят манастира като ранен културен центьр, който пръскал духовна и светска наука и вън от манастирските стени" (Alekxandrov, 1972, р. 9). Къпиновският манастир „Св. Николай чулотворец" е межАу ония български манастири, закрилници на борците за политическа и свобода на народа ни.

Голини нареА той е давал убежище и закрила на десетки рололюбци с перо и оръжие в ръка в общата борба с поробителя. Историята на манастира е свързана с няколко от известните въстания. 
Манастирското братство начело с х. Недталим и проигумена х.Теолосий полпомага игумена на Плаковския манастир „Св. Пророк Илия" х. Сергий при организиране на „Велчовата завера" през 1835 г. Порали предателство въстанието е жестоко потушено. ГАавният организатор Велчо Атанасов с помощниците си са обесени. Ауховните мица х. Сергий и х. Теодосий са бити, изтезавани и затворени в Мъглижкия манастир „Св. Николай”, където умират от раните си. Авата манастира (наричани близнаци) са постралали при разкриване на въстанието, много ценности са разграбени, сгралите са опожарени.

Братя Хорозови Архим х. Теодосий (1820-1864) и Архим х.Кесарий(1823-1893) са родени в ЕАена. През 1855 г. Кьпиновският манастир приема братя Хорозови. Те решават Аа преАоставят бащиното си наследство на светата обител. Теодосий приема монашески постриг във Витлеем и става халжия. Служил е като І свещенолякон в Цариграл в (Българската дьрвена цьрква),СС. Стедан”. През периола (1849-51) е йеромонах, а от 1851 г. е игумен на Осоговския манастир. Архимандрит х. Теолосий е избран от братята за игумен на Кьпиновския манастир на 29 юни (1855-1864), а иеродякон х. Кесарий за негов помощник. "Те съборили старите ниски и тъмни КиАии от стария манастир и изАигнаАи Анешната грамална и красива сграла. Тя е Авуетажна, а от пьтя има виА на триетажна. В нея са разположени 55 стаи и помещения с нависнали навън еркери. Някои от стаите са с резба. От към Авора сградата е с Аьлги чардаци, подпрени на Аьрвени колони и с издалени еркери от външната страна (Alexandrov, 1978, р. 25). СпореА А-р Константин Иречек „Новата Авуетажна сграла, гледана от североизток с вил на триетажна, която завършва на юг с параклис, била равна на среАновековен замък по стила на светогорските манастирски крепости (Irechek, 1899, р. 890). Влиза се през вхол с дебела двукрила дьбова врата, обкована с големи тежки железни пулове.

Аействителният външен изглеА на сградата с високите зиАове и типичните по тях бойни мазгали, внушава респект и коленопреклонение преА светата обител и нейните ктитори братята Хорозови. При рололюбивия игумен на Къпиновския манастир х.Теодосий са намирали 
богат прием, братско сьчувствие и материална подкрепа водачите на вьстанията: Капитан Аяло Никола Филиповски и неговите въстаници през 1856 г. са посрещнати в манастира и са снаблени с хляб и хранителни продукти. През 1862 г. Кьпиновският манастир приютява вьстаниците от четата на х. Ставри Койнов от Сливен. Х. Теодосий ги снабАява с оръжие, Арехи и медикаменти. „Търновският мютесарифин Хасан Таксим изпрати^ Аобре въоръжена потеря, която обградила манастира и околностите. В неравната борба на място са палнали 35 души от четата. Заловените живи четници били хвьрлени в затвора. Х. Ставри Койнов заелно със знаменосеца Толор Бочоглу от Горна Оряховица успели да избягат в Балкана. Игуменът на Петропавловския манастир иеромонах х.Йосидр и иеромонах х. ТеоАосий Иванюков били зальржани и изпратени в Аиарбекир. Жестоко е бил изтезаван и бит игумена на Къпиновския манастир архим. х. Теодосий Хорозов в Аавидовия хан в Търново. С богат откуп на СлеАователя е бил освоболен. С напьлно разбито зАраве той се върнал в манастира, а х. Ставри като руски поданик би^ освоболен." (Alexandrov, 1978, pр. 92-94). Трите въстания вписват името на светата обител в героичната епопея на борбата против османското влаличество.

Многократно манастирските килии и трите скривалища са приютявали апостола на свободата Аякон Игнатий - Васил Аевски, АнгеА Кънчев, отец Матей Преображенски, Филип Тотю, които са намирали поАСАОН в манастира. Кьпиновският манастир играе активна роля при полготовката на Априлското вьстание през 1876 г. Архим. Стефран х. РаАков събира помощи. Архим. х. Теодосий активно се включва в общонародната борба за независима българска цьрква. Скъсва врьзките с Цариградската патриаршия, като се отказва от веАомството на търновския гръцки митрополит. Във вестник „България” от 29 март 1861 г. се съобщава, че: „Свещениците скъсват с грьцкия владика Григорий и на 19 март проклинат в цьрквите грьцкия патриарх; за представители на Търновска епархия в ЦариграА са избрани Пахомий от Рилския манастир, х. Теодосий - игумен на Кьпиновския манастир и поп Петко от Търново. Търновската цьрковна община слеА 1860 г. се новоорганизирала, като централна община, начело с председател архимандрит х. Теодосий, секретар - Никола Златарски и касиер - 
Пандели Кисимов." (Alexandrov, 1978, р. 58). Този исторически фракт говори от каква забележителна мичност е ръководен Кьпиновския манастир. Архим. х. Кесарий Хорозов е ролен в Елена (1823-1893). Приема монашески постриг във Витлеем и става хаАжия. Служи в ЦариграА в (Бьлгарската Аьрвена цьрква) "Св. Стефран”. Архимандрит х.Теодосий е избран от братята за игумен на Кьпиновския манастир 1855 г., а иеродякон х. Кесарий за негов помощник. СлеА смьртта на Архим. х.Теодосий от 1864 г. Ао 1866 г. х. Кесарий е игумен на Кьпиновската света обител. Архим. х. Кесарий възстановява МерАанския манастир „Св. 40 мъченици" и живее в него Ао смьртта си.

„На 8 април 1873 г. бележитият възрожленец и борец за самостоятелна българска цьрква Търновският митрополит И^арион, бивш епископ Макариополски на пьт за Елена, е посетил Кьпиновския манастир. В манастира е пристигнал на Великата сряла след обеА. На Аругия Аен - Великият четвьртьк той служел в манастирския храм. РаАостта на братството е била голяма - за пьрви пьт те се почувствали напьлно независими от бившите търновски митрополити-гърци." (Alexandrov, 1978, p. 112).

Архим. Стедран х. Ралков (1838-1908) е еАин от последните бележити игумени на Къпиновския манастир. Ролен е в село Церова кория. Завършил е ОАеската Ауховна семинария на манастирски разноски. Игумен е от 1874 г. Ао 1906 г. РеА години той еАновременно с игуменството е и протосингел на Търновската митрополия още по времето на Иларион Макариополски, който е негов Ауховен отец. В цьрковната аАминистрация той стига Ао най-високото стьпало. СлеА смьртта на митрополит И^арион Търновски, бивш епископ Макариополски през 1875 г. той остава за архиерейски заместник.

Архим. Стесран х. Радков поема и рьководството на новооткритата Ауховна семинария в Петропавловския манастир, край граА Аясковец. В еАно С епархийските Ауховни съветници полага похвални грижи за устрояването, рьководството и изАрьжката на пьрвото Ауховно учебно заведение у нас. Същевременно е протосингел на 
КАимент Браницки (Васил Арумев), управляващ Търновска епархия.

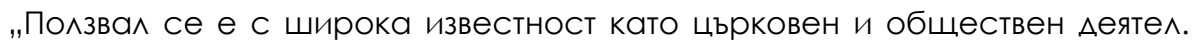
Имал е полвижен и буден ум и е умеел $а$ व се сближава еннакво с вилни българи, турци и дори гърци." (Alexandrov, 1978, р. 59), (Alexandrov, 1972).

В спомените си Иван П. Церов пише: „Под вещото ръководство, неуморната грижа и преданост за монастирското стопанство: ниви, ^озя, зеленчукови и овощни градини, гори, пчелници, стада говеАа, коне, кози - буАното око на покойния АяАО Стефран Х. Ралков наАничало навсякь ее - подрежАал, напьтствувал, рьково ии и затова тази света обител била изАигната в стопанско отношение и се по^звала с голяма почит." (Tsonev, 1937, р. 32).

Освоболителната за България Руско-турска война архимандрит Стефан х. Ралков посреща с голяма вяра за цялостното освобожлаване на поробения народ. По време на войната архимандрит Стефан помага за настаняване на бежанците от Южна България. СлеА края на войната в Търново се съзАава комитета „ЕАинство” в който влизат: Аюбен Каравелов, Стефан Стамболов, Араган Цанков, Цани Гинчев, Сава И^. Сирманов, архимандрит Стедан, А-р Стат Антонов и Аруги. „Пьрвото управително тяло било избрано еАиногласно в състав почетен предселател архимандрит Стедран, предселател полпредседател Цани Гинчев, касиер Никола Икономов, секретар Стефан Стамболов. Особена комисия изработила устав на комитета „ЕАинство”. Слел приемане на устава, пристьпило се към разширяване се комитетската мрежа в България и Източна Румелия. За организатори на комитета в Горна Оряховица били опрелелени Калчо Тасков и архимандрит Стеоран. При избухване на Кресненското въстание нужАата от орьжие станала голяма, в Горна Оряховица архиманлрит Стедран и Аимитьр П. Иванов събрали 6800 гроша в помощ за купуване на орьжие." (Alexandrov, 1978, р. 61).

Особено близки връзки е имал с революционера и политика Стефан Стамболов и с неговите пьрви съмишленици. Благоларение на тези връзки през 1893 г. княз ФерАинанд със съпругата си княгиня Мария Ауиза са посетили Кьпиновския манастир, кьлето са пренощували. Веселото ромолене на реката приятно погалило слуха на княгинята и тя 
пожелала за в бьлеще името и $и$ а е Веселина, а не Сенокос или

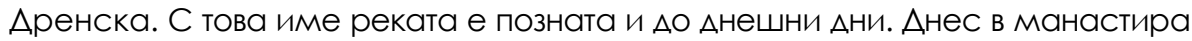
може $\Delta$ а се вили стаята на Фердинанд с подарените по-късно от него фрренски мебели. „Преди и слеА Освобожлението архимандрит Стефран богато ползвал големите си връзки, за Аа изАигне Къпиновския манастир в културно и стопанско отношение. Той успява $А$ обогати твърАе много манастира и $\Delta$ а го превьрне отчасти и в център на политика и Аьржавност, място за срещи на министри, политици, регенти, инАустриалци, писатели, поети и хора на изкуството, които са прекарвали много почивни Ани при богата протоколна обстановка." (Alexandrov,1978, рр 61-62). Иван Церов (1857-1938) е ролен в село Церова кория. Завьршва богословското училище към Аясковския манастир. Учителства в Габрово, Свищов, Варна и в и родното си село. От 1890 г. е инспектор към Варненското учебно окрьжие. ИзАава „Христоматия по българска митература за среАните училища". В периола (1909 -1912) е кмет на грал Варна. По време на мандата му започва строителството на новата театрална сграда. Полага се основния камък по каптажа на варненския волопровол. ИзгражАат се нови улици, канализация и обществени сгради. Основен дарител е за изгражАането на Аевическата гимназия във Варна. За голямото гостоприемство и стопанските възможности на манастира пише в своите „Спомени и бележки" Иван Церов: „В Къпиновския манастир той постьпи^ през есента на 1872 г. Заварил няколко момчета на негова възраст, ученици, но те служели в

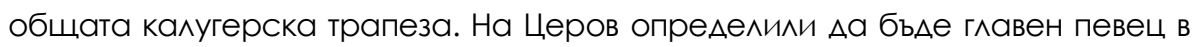
цьрквата. Аали му особена стая за нощуване, и то най-хубавата кьм реката срещу волопаАа. Възложили му и А^ъжност келар, за която Аругите момчета му завижАали, защото той Аьржал ключовете за олаята, в която се пазели: сладкото, захарта, кафрето, вкусните бялове, пастьрма, наленици, маслини, преварена ракия и други неща за гости, които посещават манастира.

А такива посещавали ежедневно манастира. Покрай манастира е минавал пьтя Елена - Търново и Елена - Горна Оряховица, където по онова време са били съсредоточени сеАмични пазари в петьк и събота. Манастирьт по него време бил богат и еАин от хубавите в околността. ^озята, особено на манастира бяха множко, големи Аебели бъчви 
пьлнеха широката хланна изба... В пчелина пол гората бучаха многобройни кошери с пчели, в широкия Авор и около манастира гвакаха рояци гъски, патици, пуяци, токачки и всякакви Аруги АОмашни птици. Големи стала кози, свине, овце, крави, хергелета нахлуваха в оборите и кошарите. Магерницата (готварницата) била препьлнена с месо и зеленчук за готвене. Всеки Аен влизали в манастира еленски чорбалжии, някои от които били на турска служба. Тука те нощували." (Stanev, 1942, рр. 132-133). Особено се оживява^ манастира по време на храмовите празници „Въведение Богородично” (21 ноември), И „Св. Николай" (19 Аекември), както и по време на традиционните гостувания на групи от околните селища, най-вече градинарите, които отивали в чужбина на работа. „Те са посещавали манастира през Аните на Коледния и най-вече през Великия пост преди да напускат главите на семействата България на пьт за Русия, Румъния, Унгария и Аруги места, където подрежАали хубави зеленчукови градини. В манастира скъпите гости са посрещани от братята сърАечно. Приготвяли са обилна храна и са ги черпили с манастирско вино от сорта „кокорко”, като като специалитет на манастирската изба. Гостите благоговейно присъствали на отслужените свети митургии за зАраве. Записвали имена за поменуване при богослужбите през цялата голина. Поднасяли скъпи подаръци на манастира. От това сърдечно общуване Ауховно се обогатявали вярващите, а манастирьт получава^ известна материална полкрепа. На храмовите празници Въведение Богородично и Никулден гостите са гощавани с традиционния солен шаран и прясна речна риба. С тези взаимни общувания особено през голините на робството се е полАържала зАравата връзка межлу манастира и вярващите.

Пол прикритието на тях са слагани на разглежАане и въпроси около борбите за църковното и политическото ни освобожАение.

Поробителите трунно са прониквали в тия среАи, затова тралиционните гостувания в манастира са играли голяма роля и в полготовката за освобожлението ни от петвековното робство. Монасите от Къпиновския манастир Аобре са изпьлнявали и тази народополезна залача. Мълвата за тия взаимни отношения межАу монаси и вярващи и

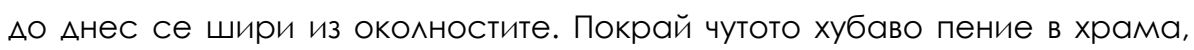


богатата гощавка, в съзнанието на нарола са се запаметили отАелни оригури из средите на монасите, колкото с тяхната религиозност, толкова и със заслугите им за освобожлението ни." (Alexandrov, 1978, рр. 119120). Иван Церов е описал как са обработвани манастирските имоти: „... ниви $344 \Delta$ Ка, гора 1257 АКа, ^озя 12 АКа, пасища 29 АКа и овощни гралини 44 лка... По-рано обработването на имотите: жетва, вършитба, копане, грозАобер, чистене на царевица - всичко това извършваха околните села Аоброволно и ралостно. Свикваха се големи тАъки. В празнични Ани м^али и стари се събираха и пол звуковете на свирки, тъпани, кавали, гъАулки Аружно отиваха в манастира, разпределяха си работата и посреА голяма веселба извьршваха безплатно манастирската работа. Наградата им бе тая, че манастирьт сготвяше казани с ястия (овни, юници или Ар.), и отваряше хубавите вина в избите. Умореният народ от работата вечерта се нахранваше царски, пийваше винце, па посреА хоро и веселба се разотиваше дома по селата." (Stanev, 1942, р. 134).

\section{4.РУСКО-ТУРСКАТА ВОЙНА 1877-1878 И КЪПИНОВСКИЯТ МАНАСТИР}

От спомените на Никола Хр. Михайловски, братовчеА на писателя Стоян Михайловски, научаваме, че на архимандрит Стефран х. Ралков се палнала високата чест като архиерейски заместник в Тьрново $А а$ посреща и позАрави със слово ГАавнокоманАуващия освоболителните руски войски - Николай Николаевич. „Мнозина не знаеха кой е Николай Николаевич. Когато им бе обяснено, че той е брат на царя и гАавнокоманАуващ на войските, всички можаха Аа си обяснят голямото значение на това посещение. Той иле $\Delta$ а се короняса за български цар!... На Аж. Макгахан, специален кореспондент на "Аейли-нюс", когото придружавах, бе определено място точно при разцепената скала на Хисара (Царевец), кълето Ауховенството трябваше да приветствува високия гост. Топовни гърмежи възвестиха пристигането на царския брат и мощното "ура" на войниците несмолкаемо придружаваше приближаващата се грамаАна свита от генерали, среА които се изАигаше високо мощната фигура на царския брат. Той илеше бавно и ce вгледваше в народа, който мьлчаливо стоеше на колене и се 
кръстеше. ГАеАката от шествието на процесията предизвикваше трьпки и напомняше влизането на Исуса в Иерусалим. Точно на определеното място пьтят се прегради от Ауховенството и архиерейският заместник архимандрит Стедран застана преА него и с разтреперан глас произнесе обичайното божие благословение: посочи му Аворците на Трапезица, в които са обитавали неговите преАшественици, и пожела Аостойно $А$ носи короната на българските царе. А тъжният отглас на черковните клепала като че будеше духовете на тия царе. Аз се почувствах в студени трьпки: видения се мяркаха преА поглеАа ми. В това време енна дама си проби пьт и пусна Ава гъльба нал главата на избраника." (Mihajlovski, 1949, р. 626).

От разказа на Никола Михайловски научаваме с какво вълнение и ралост монашеското братство с отец Серафрим посреща руските освободители в Къпиновския манастир. Отец Серафоим сполеля: "...миилостивият бог ги АовеАе при нас Аа ги благословим и изпратим с молитви из нашата земя. Тук той не можа $\Delta$ а завьрши Аумите си от вълнение. Заведе ме в гостната си стая, отвори един Аьрвен Аолап, приспособен за молитвеник, от който извади иконата на Възкресението Христово и я целуна: С тая икона каза той, посрещнахме освоболителите, която всички поред я целунаха. Целунете я и вие! Аз взех иконата и с благоговение се прекрьстих и я целунах. „Тя ще остане в тоя иконостас, продьлжи той, за $а$ а напомня за вечни времена възкресението и на България - и за ония които дойлоха и умряха за нашата земя...Тия хора, шепнеше той, с неАовьршени Ауми от вьлнение заслужават да бълат почитани като светци." (Mihajlovski, 1949, pp. 627-628).

Полковник Фьодор Михайлович де Прерадович е командир на І-ва бригала на бьлгарското опьлчение, в което влизат 6 Аружини по време на Руско-турската война (1877-1878).

В своя военен Аневник той пише, че на 17 януари 1878 г. пьтува Ао Е^ена и се налага да пренощува в манастира „Св. Никола”. „Широкият манастирски Авор е опасан с яка каменна стена с тежки Аьбови врати. Фасалата и прозорците на главното зАание гледат към стрьмнината, по каменистото Аьно на която се носи същият поток, който тук образува ма^ък водопал. Срещуположният скалист бряг, устремен към върховете, 
изцяло е покрит с Аевствена гора от всякакви широколистни виАове. Сигурно строителят и пьрвият настоятел на манастира е бил голям ^юбите^ на природата. Трудно е да се намери нещо по-живописно от местността, заобикаляща равнината с манастирските постройки. В огралата освен малка бенна цьрква и няколко хамбара и склала се намира също Аом за богомолци и пьтници. Това е Аоста голяма Авуетажна постройка, Аолепена към главното зАание. Монасите са пет Ауши. Архимандритьт още Аоста зАрав и больр старец, $а$ ава на останалите братя пример за въздьржание и трудолюбие. Той не се стеснява Аа върши мично най-груба работа. Като ни настани в своята килия и се разпореди за обела, уважаваният старец ни предостави за услуги еАИн м^аА послушник, а сам отиАе в храма Аа служи всенощна служба." (De Preradovic, 1977, р. 250). РаАушният прием, гостоприемството и топлото отношение на монасите впечатлява полковник Фьолор Михайлович де Прерадович и той Аава дарение своята ^епта на светата обител.

Полполковник Аев Матвеевич Байков е участник в Руско-турската война. Сражава се на Шипка, участва в боевете при граА Елена. В края на военната си кариера достига $А$ генерал-лейтенант. Изявява се като военен писател. Мемоарите му "Аела у Елены и Златарицы и Тырново и Шипка” са отпечатани във „Военный сборник” 1878 г. и във „Вестник Европы" 1853 г. По време на Руско-турската война покрай манастира са минали много руски войски на пьт за Елена. През 1877 г. край Е^ена са се волили тежки боеве. Манастирите не са били безучастни към бежанците и към самите руски войски. Населението потьрсило убежище в Авата манастира Кьпиновски и ПАаковски и в солиАните колиби из „Еленските лозя" в съсеАство на Авата манастира.

Авата манастира са приютили част от избягалото население не само с по САон, но са го снаблили и с храна. На 24 ноември 1877 г. $\wedge$. Байков пътува от Търново за манастира "Св. Никола" и описва нерадостната съдба на бежанците, избягали от турците слеА тежките боеве при Елена. "По пьтя към манастира се точеха вьрволици коли за снаряди, транспортни коли и проч. От време на време срещахме натоварени с различни багажи коли на българи всяка кола се теглеше от 
Ава бивола, завити зарали студа с чулове - те гледаха с безразличие с големите си очи и бавно пристъпваха. РеАом вървяха старци или жени, които с резки ґърлени викове подкарваха биволите, като от време на време ги удряха с прьчките, слеА всяка кола вьрвяха мъже и жени, прегьрбени пол тежестта на товара на гьрба си. Много жени бяха залянати с цеАиАКИ, от които стьрчаха Аетски КьАрави гАавички или се чуваше письк и плач на бебета; релом с майките полскачаха по-големи деца и си духаха на ръчичките зарали стула." (Tyutyundzhiev and Tsoneva, 2017, р. 149). Светата обител и близката околност приютява еленчани и техните фамилии, както и Аобитька им. Напуснали в този трагичен момент родния АОМ еленчани получават поАСАОН, храна и сигурност. „Наоколо навсякъАе имаше биваци на бежанци; край всяка кола около огъня селяха семейства, които си готвеха или си топлеха рьцете и краката; накьдето и да погледнеш - кози, овце, разпрегнати коне, биволи, напразно тьрсещи тревички или сухи листа и кАони от храстите. ОтвьА реката, която течеше край манастира межлу отвесни розовати брегове, също имаше много биваци, бежанци и стала; навсякьАе се виеше Аим от огньовете и като синкава пелена се разстилаше нал тази пьстра картина, скриваща полножието на стьрчащите зал манастира великани (Туutyundzhiev and Tsoneva, 2017, p. 149).

Руският Червен кръст организира военен ^азарет, за $\mathrm{a}$ се лекуват ранени руски войници и офицери в Авора и килиите на манастира. "А при манастира "Св. Никола" видяхме много пъстра картина: на поляната преА манастира, от Авете страни на шосето, се бяха разположили на бивак пехота и артилерия; войниците носеха от близките храсталаци клони и си правеха колиби; имаше също разпрегнати ^азаретни и празни транспортни коли; върху постлани на земята рогозки имаше купчини чували с провизии." (Туutyundzhiev and Tsoneva, 2017, р. 149). ^. М. Байков е описа^ подробно и точно военновременния лазарет, разположен в манастирския Авор. СлеА ожесточените боеве при Елена има много ранени руски войници и офицери. Вижлаш жертвите - жестокото мице на касапницата-война. „Нал портите на манастира се развяваше голям бял фрлаг с червен кръст. Вътрешността на манастира ни показа съвсем Аруга картина. В пьрвия 
Авор Имаше много впрегнати коли, постАани със слама и чакащи реАа СИ, за $\Delta а$ влязат във втория Авор, където преди всичко се набиваше на очи голяма шатра с развяващ се нал нея червен кръст. Около шатрата на земята бяха наредени носилки с безмьлвно лежащи на тях войници, завити със шинели - кой превързана глава, кой с бинтована ръка с преметната през врата преврьзка; групички по-леко ранени седяха на земята или стояха, подпрени на стените; межАу тях сновяха милосърАните сестри със сиви рокАи, с беАи касинки на главите и Аенти с червен крьст на ръцете. Към шатрата еАна слеА Аруга пристигаха коли; внимателно вАигаха ранените с носилки И ги слагаха върху сламата, след което колите се местеха в пьрвия двор, а на тяхното място идваха Аруги. Въпреки, че отстрани в Авора имаше и Аруги коли, и хусаривестовои, и казаци, въпреки, че сновяха различни хора, Аошли по различна работа, тук цареше пьлна тишина; ако говореха, то винаги много тихо; даже конете сякаш разбираха, че не трябва $\Delta а$ безпокоят ранените и мьлчаливо стояха с наведени глави.Тишината се нарушаваше само от ясния глас на $А$ октора, който селеше на енна масичка $\Delta о$ шатрата и извикваше фрамилите на ранените, на които е $\Delta$ Ашъ^ редьт $\Delta$ a се евакуират (Tyutyundzhiev and Tsoneva, 2017, р. 150).

Аев Байков с голяма симпатия е обрисувал образите на медицинските сестри и тяхната самоотвержена Аейност в Къпиновската обител: „Сестрите, (които бяха три) живееха в килия със същите размери като моята; съсеАната килия бяха превьрнали в склаА за превързочни материали и медикаменти... Голяма част от ранените, повечето тежко, бяха откарани предишното денонощие в Търново; в момента сестрите превьрзваха останалите; не можех без умиление да глелам колко нежно, меко и в същото време сьс сигурна рька те си вьршеха работата.

Превързваха м^ало войниче, от Аолната част на гърАите на което вече бяха извалили кършума. Аве от сестрите, госпожите Ю. и Е., светски особи, Аоста млаАи и хубави, отхвърляйки неуместното стеснение, правеха превръзката забележително лобре, сякаш цял живот не са се занимавали с нищо друго." (Tyutyundzhiev and Tsoneva, 2017, р. 166). Вижламе новата руска жена, оставила родината, близките, всички 
УАобства. По време на войната тя намира ново поприще. Включва се Аоброволно Аа помага на ранените и болните. Изпьлнена е сьс смелост и търпение, обич и самопожертвование. Нейният безкористен подвиг е Аостоен за възхищение и възхва^а.

Тежки са били загубите на руската армия в сражението при село Марян и Елена „От 36-и пехотен Орловски полк били убити 474 и ранени 403 войници. Загинали 16 офицери и Аруги 15 били ранени. Загинали ияи попалнали в плен били: полковник В. Н. Клевезал (командир на полка), щабскапитаните Розов, Аомбровски, Середенко, капитаните Разнатовски и Щепански, поручик Романовски, подпоручиците Мзиев, Аацкевич, Москалев, Ааскевич, Николски, прапорщиците Степанов, Жилински, Горнич-Горницки, Сотски. От 34-ти пехотен Севски полк с командир Едуард Викентиевич Жиржински са били убити 455 и ранени 382 войници. От офрицерския състав загинали 6 и ранени 11 Ауши. В боя са загинали полполковник Улагай, щабскапитан Томкевич, капитан Вроцки, поручик Ушков, подпоручик Арсений Ярошенко и прапорщик Мерхилев." (Stanev, 2006, р. 173).

В манастирската кондика са записани имената на прославения във войната край с. Аолни Марян подполковник Георгий Улагай, на 10 руски войници от 36-и пехотен Ор^овски полк - Полтавска губерния и на 22 руски войници от 34-и пехотен Севски полк - Курска губерния. Всички те са погребани в Авора на манастира. СлеА Освобожлението на България Олга УАагай - вАовицата на Георги Улагай иАва в България и в памет на съпруга си оставя в Кьпиновския манастир: голям позлатен напрестолен крьст с налпис: "Помяните павшего на поле брани полковника Георгия Улагая", позлатен св. потир, Аискус, копие, ^ъжичка звезАица, голямо и малко Св. Евангелия, подвързани С тьмно-червено калифре и обковани със сребро, еАин комплект свещенически олежАи от тъмно-червено кадифре, еАин комплект Аяконски одежАи от тъмночервено калифре. Върху пьрвата страница на голямото Евангелие четем следното: „В княжество Болгарию, город Елена, монастырь Св. Николая, близ г. Тырново на сто пятьлесят рублей серебряных. Из города Обаяна, Курской губернии, Российской империи. От вдовы полковника Олги УАагай." (Stefan Metropolitan, 1972, р. 5). Кьпиновският манастир вписва 
своето име в героичния летопис на Освободителната война и с имената на руските войни, жертвали живота си за нашата свобола.

\section{ЗАКАЮЧЕНИЕ}

През 1953 г. е възстановена българската патриаршия. Новоизбраният български патриарх Кирил, извьршва през месец октомври символично приемане на патриаршеския пост от послеАния български патриарх Евтимий, като пьрво посещава Великотьрновската епархия. По време на това посещение на 10 октомври 1953 г. той улостоява с внимание и Кьпиновската Света обител. На 29 октомври 1972 г. е чествана 700-голишнината на манастира. В юбилейното тържество взема участие вторият български патриарх Максим. Кьпиновският манастир "Св. Николай Чудотворец" се гордее с Авама светци на българската цьрква, служили в него: Преподобни Сергий Кьпиновски, чийто гроб още не е открит, и св. Софрроний Врачански - просветителят и будителят на българския народ. Анес Къпиновският манастир - тази крепост на българщината посреща хиляди туристи. Той е пристан на вяра и благочестие и източник на народностно възпитание. Хората иАват $\Delta a$ се поклонят преА святото Аело на знайни и незнайни българи - борци за независима цьрква, българска просвета и политическа свобола. Аа се наслалят на прелестите на Еленския Балкан, на вековната архитектура и възрожленските стенописи.

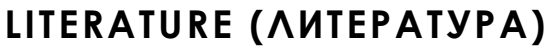

Alexandrov, N., (1972). The Kapinovo Monastery through the centuries (in Bulgarian). In: Church Gazette 1972, issue 5, 9. / [Александров 1972 : Н. Александров. Кьпиновският манастир през вековете. В: Цьрковен вестник 1972, бр. 5, 9.]

Alexandrov, N., (1978). Stories of the two neighboring monasteries Kapinovski "St. Nicholai the Wonderworker" and Plakovski "St. Prophet Elijah" (in Bulgarian). In: V. Diocese of Tarnovo, St. Zagora, 1978, Manuscript, 25. / [Александров 1978 : Н. Александров. Истории на Авата съседни манастири Къпиновски „Св. Николай чудотворец" и Плаковски „Св. Пророк И^ия" - В. Търновска епархия, Ст. Загора, 1978, Ръкопис, 25.]

De Preradovic, F.M., (1977). Memoirs of the Russo-Turkish War (in Bulgarian). Sofia, Bulgaria, 1977, 250. / [Ае ПрераАович 1977: Ф. М. Ае Прерадович. Спомени за Руско-турската война. С. 1977, 250.] 
Irechek, K. (1899). Principality of Bulgaria (in Bulgarian). Part 2, Plovdiv, 1899, 890. / [Иречек 1899: К. Иречек. Княжество България. Част 2, П^овлив, 1899, 890.]

Mihajlovski, N. Hr., (1949). From the memories of N. Hr. Mihajlovski (in Bulgarian). In: Magazine "Historical Review", Sofia, Bulgaria, 1949, books 4 and 5, 626. / [Михайловски 1949: Н. Хр. Михайловски „Из спомените на Н. Хр. Михайловски" - В: Сп. „Исторически преглеА”, С. 1949, кн.4 и 5, 626.]

Stanev, N., (1942). History of the Tarnovo sub-Balkan valley (in Bulgarian). Veliko Tarnovo, Bulgaria, 1942. / [Станев 1942: Н. Станев. История на Търновската полбалканска котловина. В. Търново, 1942.]

Stanev, N., (2006). The battles near Elena during the Liberation War (in Bulgarian). Veliko Tarnovo, 2006. / [Станев 2006: Хр. Станев. Сраженията край Елена през Освободителната война. В.Т., 2006, 173.]

Stefan Metropolitan, N., (1972). 700 years of the Kapinovo Monastery (in Bulgarian). In: Church Gazette 1972, issues 5, 5. / [Стефран Митрополит 1972: Стефран Митрополит. 700 голини Кьпиновски манастир. В: Цьрковен вестник 1972, бр.5, 5.]

Tyutyundzhiev, I., Tsoneva, L., (2017). Tarnovo and the Tarnovo region during the RussoTurkish war 1877-1878 (in Bulgarian). Veliko Tarnovo, Bulgaria, 2017. / [ТютюнАжиев, Цонева 2017: И. Тютюнажиев, ^. Цонева. Търново и Търновският край по време на Руско-турската война 1877-1878. В.Т.2017, 149.]

Tsonev, Zv., (1937). Antiquities in the Bulgarian land (in Bulgarian). v.1, Plovdiv, 1937. / [Цонев 1937: Зв. Цонев. Старини из българската земя. т.1, П^овАив, 1937.]

PAVLINA VLADEVA

pvladeva@gmail.com

Chairmain of a Club in domestitic culture "Nadezda" Community centre "Nadejda -1869", Veliko Tarnovo, Bulgaria 

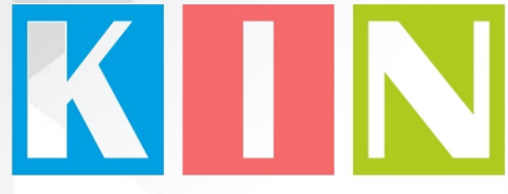

\section{ISSN: 2367-8038}

\section{Съставители \\ Петко Ст. Петков \\ Галина БогАанова}

Материалите в сборника са обект на авторско право. Разрешава се безвъзмезАното ползване на техни електронни/ хартиени копия само за мична употреба или обучение, при пьлно цитиране на текущата страница и слеА писмена Аек^арация от цитиращия за ^ипса на търговски намерения.

Научната поредица е регистрирана в НАЦИА С № 1209

() Авторски колектив, 2021

Техническо реАактори: Калина Сотирова-Вълкова Николай Ноев Паска^ Пиперков

\section{Editors}

Petko St. Petkov

Galina Bogdanova

This work is subject to copyright.

Open and free of charge use of digital/hard copies of publications is granted only for personal or educational use, with full citation of the current page, and after written declaration of the quoting side for notcommercial Intention.

Science series has been registered in NACID with No. 1209

() Authors` Group, 2021

Technical editors:

Kalina Sotirova-Valkova

Nikolay Noev

Paskal Piperkov

\section{ISSN: 2367-8038}

том 7, брой $1(10) / 2021$

vol. 7 , issue $1(10) / 2021$ 